\title{
Catch Trends of Artisanal Fisheries in Ghana, West Africa
}

\section{Emmanuel K Dovlo*}

Fisheries Scientific Survey Division, Fisheries Commission, Ghana

*Corresponding Author: Emmanuel K Dovlo, Fisheries Scientific Survey Division, Fisheries Commission, Ghana.

DOI: 10.31080/ASAG.2020.04.0815
Received: February 18, 2020

Published: February 27, 2020

(C) All rights are reserved by Emmanuel K

Dovlo.

\begin{abstract}
In recent times, artisanal pelagic fishery which constitute the mainstay of Ghanaian fisheries have shown a decline leading to low economic output in coastal fishing communities. Trend analyses were performed on artisanal fish catch, catch per unit effort (CPUE), number of canoes (or artisanal vessels) and upwelling index from 1990 to 2016. Pearson Correlation investigated the relationship between catch and fishing effort, number of canoes and upwelling index. Round sardinella and anchovy constituted major artisanal pelagic fish species contributing $24 \%$ and $25 \%$ to artisanal fish production respectively. Catches of round sardinella declined sharply after 2006 with an average catch over last three year constituting 17\% of maximum historical recorded catch in 1992. T-test however revealed no significant differences in catches of round sardinella and anchovy. There was a decline in catch, CPUE, upwelling index and an increase in number of canoes. A relatively stronger and negative relationship between catch and number of canoes indicated the major cause of dwindling catch was the higher number of canoes. Catch however had a positive relationship with fishing effort (number of days) and upwelling index. The number of canoes increased by $44 \%$ and the average CPUE was $322 \mathrm{~kg} / \mathrm{day}$. It is recommended that number of canoes are reduced to promote sustainable exploitation of the resource. This can lead to high economic output in coastal fishing communities to improve livelihood.
\end{abstract}

Keywords: Fishery; Catch Per Unit Effort (CPUE); Anchovy

\section{Introduction}

Ghana is one of the major fishing nations in West Africa and is bordered on the south by the Gulf of Guinea (GOG). The artisanal pelagic fishery constitutes the mainstay of the fisheries with round sardinella and anchovy as the major species. The round sardinella is exploited during the major upwelling season which occurs from July to September whilst anchovy is exploited all year round. The primary ocean dynamics in GOG relates to the equatorial upwelling and seasonal coastal upwelling along coast of Cote d'Ivoire and Ghana [1]. Sea surface temperature (SST) is an important signal of upwelling in the GOG and upwelling takes place when SST drops below $26^{\circ} \mathrm{C}$ for a continuous period of a fortnight. The GOG has an average SST of $22.5^{\circ} \mathrm{C}$ during the major upwelling season [2].

The artisanal fishery is the largest sector with higher number of vessels and contributes more than 70 percent of landed fish. It provides fish for local consumption and employ 80 percent of Ghanaian fishers. The artisanal fisheries sector in West Africa is labor intensive, operates near the shores and provides fish for local communities [3]. The artisanal Ghanaian fishery employs a multiplicity of gears and is categorized into five main gears for statistical purposes namely purse seine, beach seine, set gill net, drift gill net and hook and line. There was a total of 11,583 canoes of which 3,346 are was pursing net ("Poli/Watsa") canoes, 1,084 beach seine canoes, 1,344 hook and line canoes, 3,729 set nets canoes, 1,052 gill net ("Ali") canoes, 836 drift net canoes and 192 one-man canoes [4]. The gears operate from dug-out canoes, majority of them pow- ered by outboard motors with power ranging from 25 to 40 horse power. There are 292 fish landing sites or beaches from 186 fishing villages along a $550 \mathrm{~km}$ stretch [4]. The length of a canoe varies from any length up to 6 metre for a one-man canoe to 19.5 metres for the purse seine nets and drift gill net canoes [4]. Doyi [5] describes the various gears used in the artisanal fishery in Ghana.

Artisanal fisheries in West Africa face numerous challenges including climate change and overexploitation [6]. The Ghanaian artisanal fishery is no exception and have shown a declining trend in catch in recent times. The aim of this paper is to ascertain the status of artisanal fisheries and suggest measures to ameliorate the situation.

\section{Materials and Methods}

Study area

Figure 1

\section{Fish catch and effort data}

Artisanal fish catch and effort data from 1990 to 2016 was obtained from Fisheries Scientific Survey Division (FSSD). FSSD undertakes a canoe catch assessment survey of common fish species in Ghana using stratified sampling scheme. The sampling strategy employs sampling in space and in time. FSSD take records of fish catch and fishing effort from 52 fish landing sites out of 292 fish landing sites for estimation of annual fish landings. Selection of 52 fish sampling sites is based on canoe frame survey which provides an inventory of distribution of canoe/gear in 292 fish landing sites. A three-stage sample survey is designed for collection of data. At the primary sampling stage, sampling sites together with canoe/ 


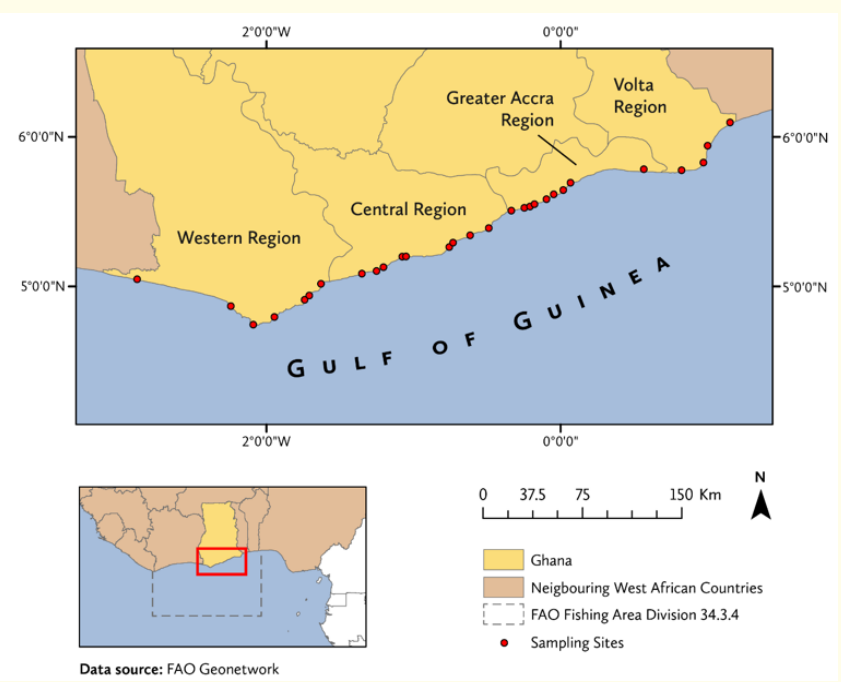

Figure 1: Map of the study area showing artisanal fish sampling sites in Ghana.

gears are selected at the minor strata which is the coastal districts. The four coastal regions represent major strata and districts within each region are associated minor strata. The secondary sampling unit is the sampling days for data. FSSD enumerators conduct sampling at least 5 days in a week at a sampling site, excluding fishing holidays, mostly Tuesday. The tertiary sampling unit is the number of canoes/gear to be sampled for a day. A maximum of 10 canoes/gears are sampled randomly in a day. Enumerators record the weight (kg) and value (GHS) of each fish species in the catch in each sampled canoe. The duration of fishing trip is recorded for each sampled canoe as fishing effort (days). Other daily information on fishing activity at the sampling site are recorded. The catch and effort data collected for each month is transmitted to FSSD and inputted into ARTFISH software for estimation of monthly fish landings for each monitored species by canoe/gear for a minor stratum. The total fish landings for each species in a year is the sum of estimated monthly catches of the species.

\section{Calculation of upwelling index and CPUE}

Upwelling index in the upwelling region of GOG has been examined mainly through analyses of SST. The formula for computation of upwelling index is:

$\mathrm{I}=(26-\mathrm{t}) \times \mathrm{N}$

Where I is the index for a fortnight, $\mathrm{t}$ is the mean of temperatures lower than $26^{\circ} \mathrm{C}$ within the fortnight and $\mathrm{N}$ is the number of days in the fortnight for which temperatures were lower than $26^{\circ} \mathrm{C}$ [7]. The upwelling index was computed from data at a reference coastal observation station in Tema.

CPUE was computed by dividing the catch (Kg) by effort (number of days fishing).

\section{Graphical analyes}

Plots were made to show trend of major fish species in artisanal catch, catch with respect to number of vessels and upwelling index, and CPUE variations.

\section{Statiscal analyses}

T-test was performed to determine if there were any significance differences in the catches between round sardinella and anchovy. Pearson correlation was conducted between catch and the number of vessels, fishing effort (number of days) and upwelling index.

\section{Results}

Round sardinella and anchovy constituted the major artisanal pelagic fish species contributing $24 \%$ and $25 \%$ respectively to annual artisanal fish production. Flat sardinella contributed $6 \%$ whilst chub mackerel and frigate mackerel contributed $3 \%$ each. Burrito and seabreams contributed $6 \%$ and $4 \%$ respectively. Round sardinella started declining sharply after 2006 and there was a gradual decline in the rest of the species, both pelagic and demersal (Figure 2).

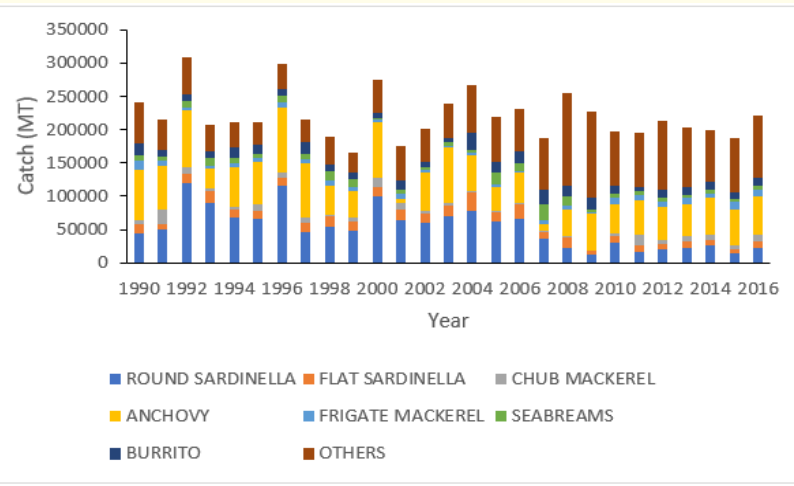

Figure 2: Trend of major species in artisanal fishery in Ghana from 1990 to 2016.

There was a decline in catch with an increase in fleet and the highest and lowest catch were recorded in 1992 and 1999 respectively (Figure 3). The fleet increased by $44 \%$.

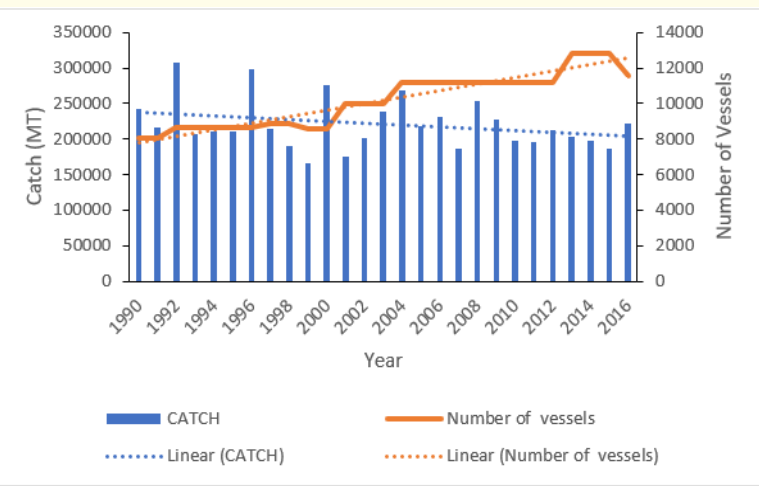

Figure 3: Trend of catch and number of artisanal vessels in Ghana from 1990 to 2016.

Catches of small pelagic and upwelling index showed a declining trend with low levels of round sardinella and lower upwelling indices after 2006 (Figure 4). The average round sardinella catch over the last three year constituted $17 \%$ of the maximum historical recorded catch in 1992. 


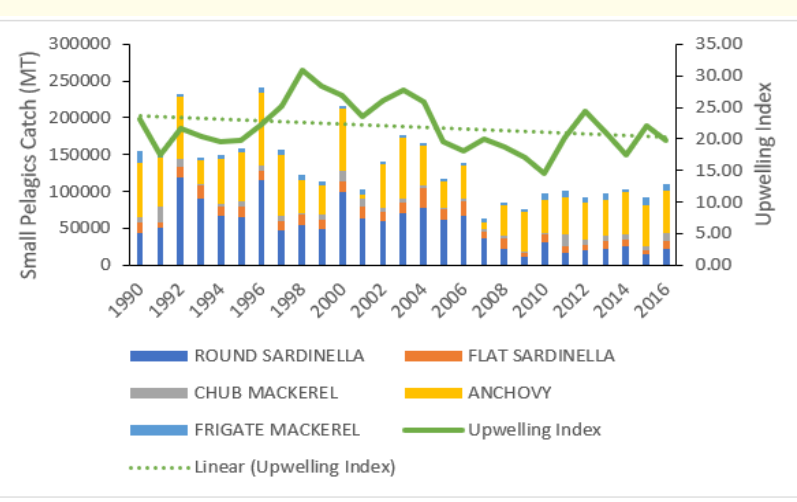

Figure 4: Trend of major artisanal small pelagic catch and upwelling index in Ghana from 1990 to 2016.

Small pelagic CPUE declined and the minimum and maximum recorded in 2007 and 1996 respectively (Figure 5). The average CPUE was $322 \mathrm{~kg} /$ day.

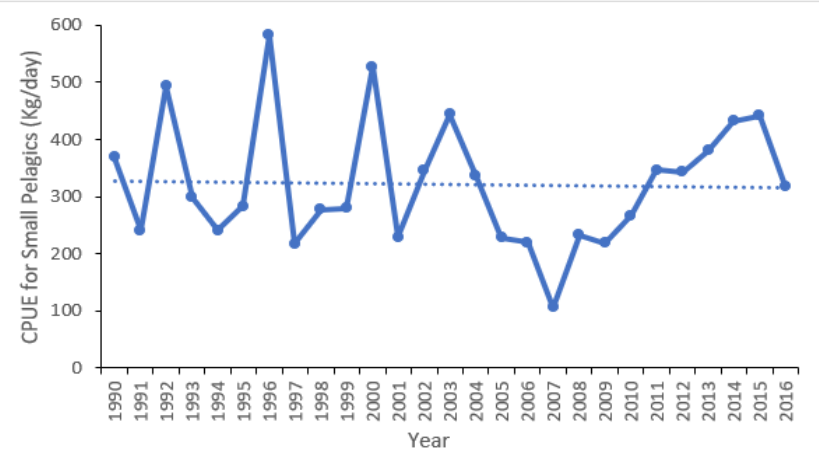

Figure 5: Variations in artisanal small pelagic CPUE in Ghana from 1990 to 2016.

There were no significant differences in catches between round sardinella and anchovy $(p>0.05)$ (Table 1$)$.

\begin{tabular}{|l|c|c|}
\hline \multicolumn{2}{|l|}{ F-Test Two-Sample for Variances } & Round Sardinella \\
\hline Mean & 52575.62737 & 54888.51035 \\
\hline Variance & 916083335.9 & 27 \\
\hline Observations & 27 & 26 \\
\hline df & 26 & \\
\hline F & 1.999200483 & \\
\hline P(F<=f) one-tail & 0.041600869 & \\
\hline F Critical one-tail & 1.929212675 & Anchovy \\
\hline t-Test: Two-Sample Assuming Unequal Variances & & 45888.51035 \\
\hline & Round Sardinella \\
\hline Mean & 52575.62737 & 27 \\
\hline Variance & 916083335.9 & \\
\hline Observations & 27 & \\
\hline Hypothesized Mean Difference & 0 & \\
\hline df & 47 & \\
\hline t Stat & -0.324185418 & \\
\hline P(T<=t) one-tail & 0.373618015 & \\
\hline t Critical one-tail & 1.677926722 & \\
\hline P(T<=t) two-tail & 0.747236031 & \\
\hline t Critical two-tail & 2.011740514 & \\
\hline
\end{tabular}

Table 1: Result of t-test for round sardinella and anchovy catches.

There was a negative correlation between catch and number of vessels $(-0.26)$. There were positive correlations between catch and fishing effort (number of fishing days) $(0.10)$ and catch and upwelling index (0.02) (Table 2).

\section{Discussion}

Decline in fish catch can be attributed to the increasingly higher number of vessels as revealed by the relatively stronger and negative correlation of catch to number of vessels. The observed higher percentage increase in the number of vessels coupled with lower

\begin{tabular}{|l|c|c|c|}
\hline \multicolumn{1}{|c|}{ Catch } & No. of vessels & Effort (No. of fishing days) & Upwelling index \\
\hline No. of vessels & -0.259856592 & & \\
\hline No. of fishing days & & 0.094323725 & \\
\hline Upwelling index & & & 0.016500435 \\
\hline
\end{tabular}

Table 2: Correlation analyses between fish catch and number of vessels, number of fishing days and upwelling index. 
catches led to declining CPUE. There has been a strong decline in artisanal fisheries CPUE in West Africa, with approximately onethird reduction since 1950 [3].

Positive correlation between catch and upwelling index indicated that weakening upwelling have had effects on the depleting stocks. The sharp decline in abundance of round sardinella in Ghanaian artisanal pelagic fishery can be attributed to the weakening upwelling associated with the warming trend observed in the region. Weakening upwelling have had effect on the zooplankton availability on which small pelagic such as round sardinella feed on. The decline in zooplankton volume was attributed to warming trend associated with global climate change [8]. Changes in aquatic environment can have significant impacts on behaviour of some species of fish [9]. Environmental changes have had effect on growth, distribution and abundance of round sardinella in the western Gulf of Guinea [10]. Though catches of round sardinella has declined to $17 \%$ of the maximum historical recorded catch, there were no significant differences in the catches of the round sardinella and anchovy. This indicates a reduction in the number of vessels can alleviate the problem and restore the round sardinella fisheries to sustainable levels.

\section{Conclusion}

Round sardinella and anchovy constituted the major pelagic species contributing $24 \%$ and $25 \%$ to artisanal catch respectively. Catches of round sardinella declined sharply after 2006 and its average catch over last three year constituted $17 \%$ of maximum historical recorded catch. The major factor associated with the decline in catch was the increased number of vessels. The number of vessels increased by $44 \%$ contributing greatly to declining CPUE. The average CPUE was $322 \mathrm{~kg} /$ day. It is recommended the number of vessels is reduced to ensure sustainable exploitation of the resource.

\section{Bibliography}

1. Ingham MC. "Coastal Upwelling in the north western Gulf of Guinea". Bulletin of Marine Science 20 (1970): 2-34.

2. Dovlo EK. "Seasonal variations in temperature and salinity in the Gulf of Guinea". Journal of Aquaculture and Marine Biology 4.2 (2016): 00074.

3. Belhabib D., et al. Conservation Letters, January/February. Wiley Periodicals, Inc. 11.1 (2018): 1-10.

4. Dovlo E., et al. Report on the 2016 Ghana Marine Canoe Frame Survey, Information Report No. 36, Fisheries Scientific Survey Division, Tema (2016).

5. Doyi BA. Catalogue of Small-scale fishing gear of Ghana, CECAF/ECAF series 84/31 (en) FAO Rome (1984).

6. Belhabib D., et al. "Overview of West African fisheries under climate change: impacts, vulnerabilities and adaptive responses of the artisanal and industrial sectors". Marine Policy 71 (2016): 15-28.
7. FRU/ORSTOM. Rapport du Groupe de Travail sur la sardinelle (Sardinella aurita) des cotes ivoiro-ghaneenes, 28 juin -3 juillet, 1976, Abidjan, Cote d'Ivoire. Paris: ORSTOM Editions (1976): 62 .

8. Wiafe G., et al. "Impact of climate change on long-term zooplankton biomass in the upwelling region of the Gulf of Guinea". ICES Journal of Marine Science 65 (2008): 318-324.

9. Baird D., et al. "The comparative ecology of six marine ecosystems". Philosophical Transactions of the Royal Society, London B 333 (1991): 15-29.

10. Pezennec 0. "Ecological importance of the Ivorian and Ghanaian minor upwelling season". In Dynamics and Use of Sardinella Resources from Upwelling off Ghana and Ivory Coast. Edited by F. X. Bard and K. A. Koranteng. Paris: ORSTOM Editions (1995): 324-345.

\section{Assets from publication with us}

- Prompt Acknowledgement after receiving the article

- Thorough Double blinded peer review

- Rapid Publication

- Issue of Publication Certificate

- High visibility of your Published work

Website: www.actascientific.com/

Submit Article: www.actascientific.com/submission.php Email us: editor@actascientific.com Contact us: +919182824667 